\title{
PERCEPTION OF CAR SHARING SERVICE IN THE OPINION OF ITS USERS
}

\author{
Agnieszka DUDZIAK \\ University of Life Sciences in Lublin, Department of Power Engineering and Transportation, Subdepartment of \\ Logistics and Business Management; agnieszka.dudziak@up.lublin.pl, ORCID: 0000-0002-4884-5403
}

Purpose: The purpose of this paper is to identify the determinants of behaviour of drivers with regard to the possession and use of cars and their approach to the alternative which allows to rent cars in the market today - the so-called car sharing service, which is becoming increasingly popular and consists in using a vehicle without having to own it.

Design/methodology/approach: For the purposes of this article a survey was conducted among current and potential users of the car sharing service. The purpose of this publication was also to gain knowledge on the market's needs in terms of mobility and consumer perception of the services of car rental companies.

Findings: According to the respondents' opinion, factors affecting the decision to use the car sharing service were verified in the surveys. Attention was paid to such issues as the availability of parking spaces for cars in the car sharing service, the price of this service and a modern fleet of vehicles made available in the service.

Research limitations/implications: It is advisable to carry out further scientific research in the field of the use of car sharing services due to the fact that it is an increasingly popular way of communication, mainly among the inhabitants of urban agglomerations.

Practical and social implications: The approach to car ownership is changing. Young people are increasingly giving up car ownership and prefer its use. They do not have to pay for the purchase of the car, its operating costs, insurance or garage. The car sharing service is a convenient form of using a car without unnecessary expenses.

Originality/value: The transport services market is constantly expanding, both in the field of the carriage of goods and passengers. The number of cars per capita increases year after year, which directly translates into increased number of cars on the roads in Poland and in the world. The problem is most evident in large city centres where car parks are overcrowded and urban infrastructure is unable to cope with the growing number of cars. This was the reason for addressing the issue of changing the current model of passenger movement that could solve the problem of crowded cities.

Keywords: car sharing, share economy, automotive market, sustainable consumption, reduction of pollution.

Category of the paper: Research paper. 


\section{Introduction}

At present, different methods and strategies are used to discourage residents from using individual transport and to persuade them to use other modes of transport, such as public transport. This objective can be achieved by introducing high parking charges in the city and closing streets for individual transport. Unfortunately, although public transport is cheaper and more efficient on short distances, most of the population still choose their own cars instead of public transport. Today, many companies are investing in smart products and services. This situation applies not only to products such as mobile phones or electronic equipment, but also to cars (Łuczak et al., 2016). Car sharing can be used as an alternative to cars used for own needs (Bellos, Ferguson, \& Toktay, 2017; Leveque, 2011).

The leaders in car sharing are Europeans. Many difficulties are caused by using their own cars in the centres of large European cities, because they are very crowded. In accordance with the share economy principle, which was born in other areas of life and consists in sharing or making available the goods owned, city residents started to benefit from the new car sharing systems (Bellos et al., 2017; Guo, Xin, Jia, Barnes, \& Wang, 2018; Shaheen, 2016).

According to the data from February 2016, the biggest number of people using the shared cars was in Germany ( 1 million users), which was $1 / 3$ of all European users of the car sharing systems (Münzel, Boon, Frenken, \& Vaskelainen, 2018). It is estimated that by 2025 the number of shared car users will increase from 7.9 million to 36.37 million. According to Frost \& Sullivan, expansion of the car fleet (the total number of cars in 2015 was 111,846) may be tripled by 2025 (Leveque, 2011). About 140 different car sharing companies operate on the German market. In contrast, there are already around 3,000 vehicles operating in this system in Berlin. In Poland, car sharing services are provided by companies such as Traficar, 4Mobility and Panek carsharing.

\section{Concept of car sharing within the theory of sharing economy}

Ubiquitous increase in the number of cars on the roads makes it more difficult to park a car in the city centre. Urban infrastructure is unable to cope with the growing number of cars.

City authorities are trying to discourage car users from using their own cars, especially in city centres. They do this by introducing different types of legislation. This can also be achieved by introducing high parking charges in the city and closing streets for individual transport. Unfortunately, the car is still a popular mode of transport despite the fact that public transport is cheaper and more recommended. A system can be a solution for those who wish to travel by car, but not their own car. Over the last few years, the rapid growth in the number of 
smartphones and related applications has contributed to the rapid development of an online sharing economy, such as Uber, Airbnb, Lyft, Turo and Peerby. These emerging online peerto-peer platforms, collectively referred to as shared consumption, earn a lot of money, allowing individuals to share unused resources and earn a significant income (Guo et al., 2018). The growing popularity of peer-to-peer platforms (hereinafter referred to as $\mathrm{P} 2 \mathrm{P}$ ) is directly related to the profound transformations that can be observed in the contemporary world (Sztokfisz, 2018). The main thesis put forward by Sztokfisz (2018) is that P2P markets expand the range of economic freedom in two dimensions - by reducing entry barriers and by reducing transaction costs.

The cost of using the car sharing service is much lower than the cost of hiring a car from a traditional car rental company or using a taxi. Considering the total cost of owning a car and the obligations that this entails (registration fees, insurance costs, servicing, parking) car sharing becomes an attractive alternative for people who do not use a car on a daily basis. Most car sharing companies allow users to take and leave vehicles at any point within the city limits and the user does not have to worry about washing or refuelling the rented car which is an additional argument that may decide on the choice of the mode of transport in the city. As opposed to traditional car sharing, there are no fixed stations and in particular one-way trips of any length are possible without a booking requirement. It can be said that car sharing is something between cheaper public transport and relatively expensive taxis.

One more important issue is the sense of trust in companies operating in the share economy area. According to the PwC's report „The Sharing Economy” published in the United States, $69 \%$ of respondents do not trust companies in the share economy sector until they are recommended by a trusted person. This is also confirmed by the Polish results of research, where $60 \%$ of respondents, when assessing the credibility of sharing economy, are guided by the opinions of friends (PwC, 2016).

\section{Materials and methods}

The subject of the conducted research was the analysis of the approach to car sharing service among the inhabitants of the Lublin region and gathering knowledge about the market's needs in the field of innovative ways of mobility and perception by users of the concept of car sharing services provided by car rental companies. The research was carried out using the author's questionnaire. The number of respondents was 150. Respondents were of different ages, education, occupation, inhabited areas with diversified number of population, and had a varied professional status. Respondents answered questions related to mobility, their preferred means of transport, the use of traditional and innovative forms of car rental, and, above all, factors that distinguish car sharing from the traditional forms of transport. The main focus of the study was 
to identify the factors that determine the choice of mode of transport. The responses provided by respondents have made it possible to develop and analyse the results of the studies presented in the following part of the article.

\section{Results and discussions}

The research was conducted among various groups of respondents. Among the respondents, the majority declared that they have a driving license (about 78\%). They were mainly young (aged 26-40 - approx. 36\% of respondents) and very young respondents (aged 19-25 - approx. $30 \%$ of respondents), while most of them lived in cities of over 300,000 residents (about $58 \%$ of respondents) and rural areas (about $20 \%$ of respondents). The main group were people with a professional status - office worker (about $30 \%$ of respondents) and people running a business (about $22 \%$ of respondents). The characteristics of individual respondents' data are presented in Table 1.

Table 1.

Socio-demographic profile of the population surveyed

\begin{tabular}{|c|c|c|}
\hline Socio-demographic profile & Number of respondents & Percentage share \\
\hline Total: & 150 & 100.0 \\
\hline $\begin{array}{l}\text { Gender: } \\
\text { female } \\
\text { male }\end{array}$ & $\begin{array}{l}61 \\
89\end{array}$ & $\begin{array}{l}41.0 \\
59.0\end{array}$ \\
\hline $\begin{array}{l}\text { Age: } \\
\text { to } 18 \text { years } \\
19-25 \text { years old } \\
26-40 \text { years old } \\
41-60 \text { years old } \\
60 \text { years old and older }\end{array}$ & $\begin{array}{c}3 \\
45 \\
54 \\
42 \\
6\end{array}$ & $\begin{array}{c}2.0 \\
30.0 \\
36.0 \\
28.0 \\
4.0\end{array}$ \\
\hline $\begin{array}{l}\text { Education: } \\
\text { primary } \\
\text { secondary } \\
\text { university }\end{array}$ & $\begin{array}{l}15 \\
54 \\
81\end{array}$ & $\begin{array}{l}10.0 \\
36.0 \\
54.0\end{array}$ \\
\hline $\begin{array}{l}\text { Place of residence: } \\
\text { rural area } \\
\text { city to } 100,000 \text { residents } \\
100,000-300,000 \text { residents } \\
\text { city with more than } 300.000 \text { residents }\end{array}$ & $\begin{array}{l}30 \\
12 \\
21 \\
87\end{array}$ & $\begin{array}{c}20.0 \\
8.0 \\
14.0 \\
58.0\end{array}$ \\
\hline $\begin{array}{l}\text { Professional status } \\
\text { unemployed } \\
\text { own business } \\
\text { pensioner } \\
\text { worker } \\
\text { office worker } \\
\text { farmer } \\
\text { student }\end{array}$ & $\begin{array}{c}9 \\
33 \\
9 \\
27 \\
45 \\
3 \\
248\end{array}$ & $\begin{array}{c}6.0 \\
22.0 \\
6.0 \\
18.0 \\
30.0 \\
2.0 \\
16.0\end{array}$ \\
\hline $\begin{array}{l}\text { Driving license } \\
\text { yes } \\
\text { no }\end{array}$ & $\begin{array}{c}117 \\
33\end{array}$ & $\begin{array}{l}78.0 \\
22.0\end{array}$ \\
\hline
\end{tabular}

Source: the authors' own studies. 
The results of the survey show that among the surveyed car users the largest age group was 26-40 years old among women, whereas among men this group was 19-25 years old and 26-40 years old. The declaration concerning the use of a car in these groups was the highest of all age groups.

а)

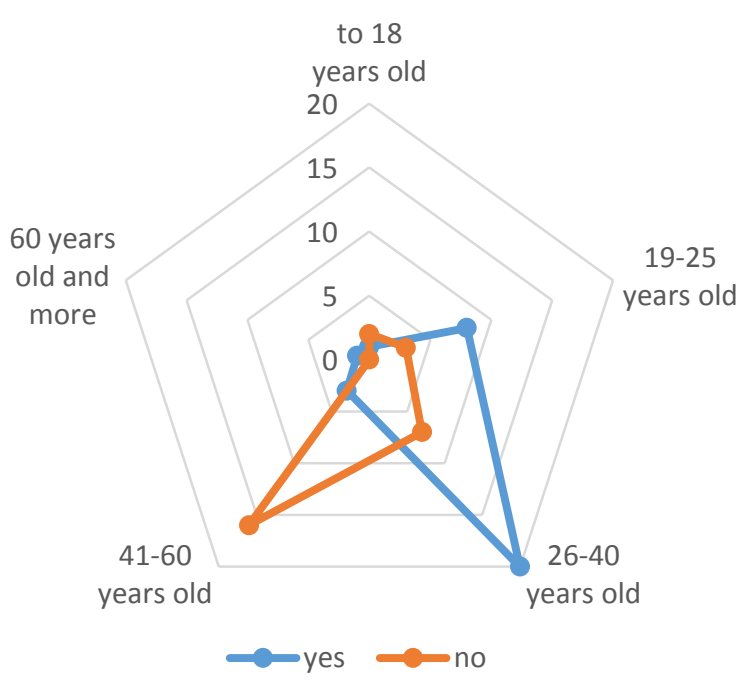

Figure 1a. Car use by women. Source: the authors' own studies. b)

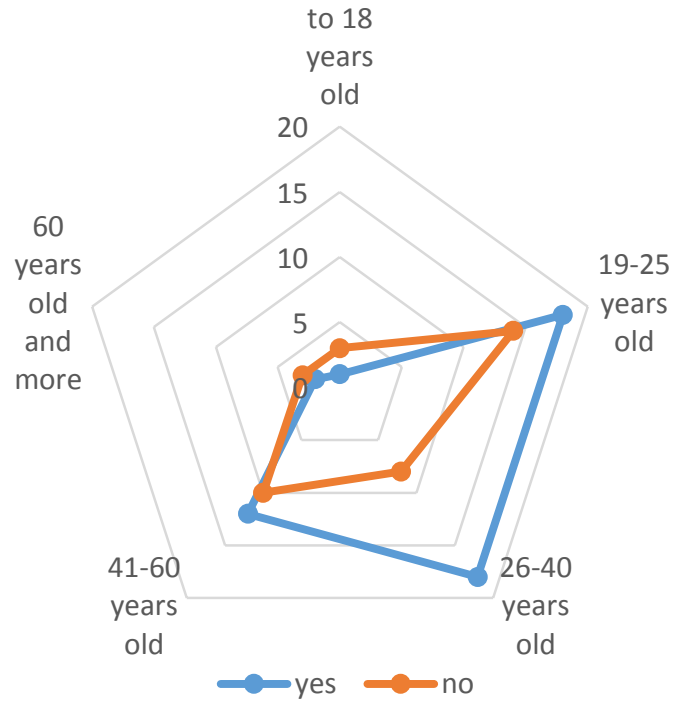

Figure 1b. Car use by men. Source: the authors' own studies.

The fact of knowing the concept of car sharing does not necessarily mean using it. The respondents' declarations regarding knowledge of car sharing vary considerably depending on the age of the women interviewed. Most of women aged 26-40 have heard about the service, but also declare that they have never used the service (Figure 2).

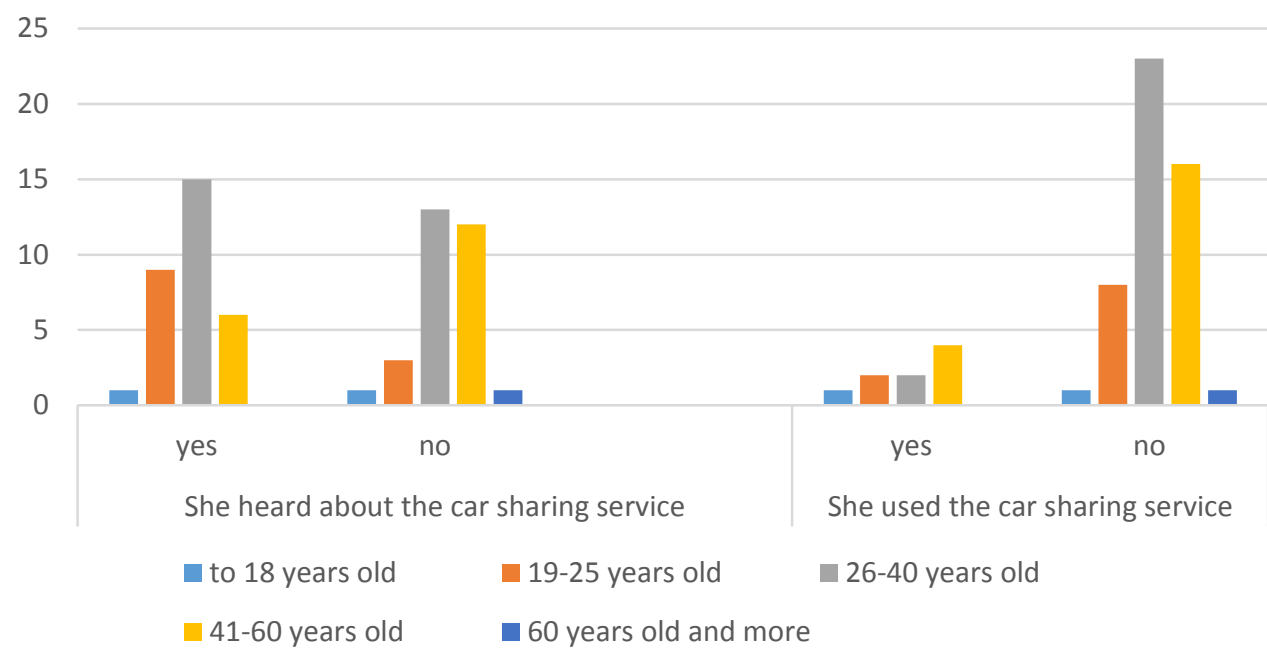

Figure 2. Declaration of knowledge of car sharing and the use of car sharing services among women. Source: the authors' own studies.

Among the group of interviewed men the situation seems a bit different, because the respondents' declarations regarding the issue of sharing cars differ significantly among men only in the group of people aged 19-25, because the respondents have heard about but not used the service. On the other hand, majority of male respondents in the age group of 26-40 and 
41-60 years old claimed that they heard about the service and at the same time declare that they have used the service (Fig. 3).

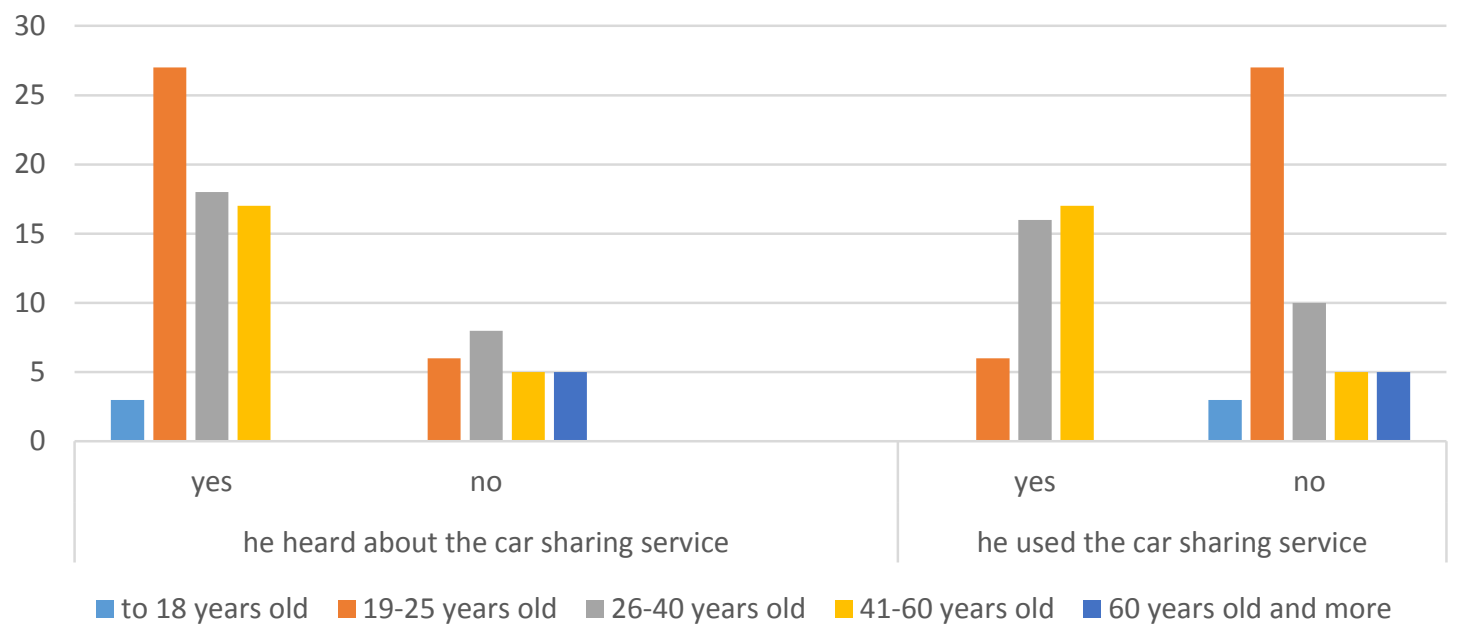

Figure 3. Declaration of knowledge and use of car sharing services among men. Source: the authors' own studies.

Data relating to the transport services market clearly show that cars rented for minutes are increasingly popular in Poland. The service is also available in the version for delivery vehicles. According to the $\mathrm{PwC}$ analyses presented in the report The five dimensions of automotive transformation, in 2030 every third kilometre travelled in Europe will be in formula of car sharing. It is estimated that in the coming years the market will grow by 30 percent each year. According to Frost \& Sullivan, by 2025 the number of car sharing users is to increase to 36 million, and the fleet of available cars is expected to increase to 427,000 .
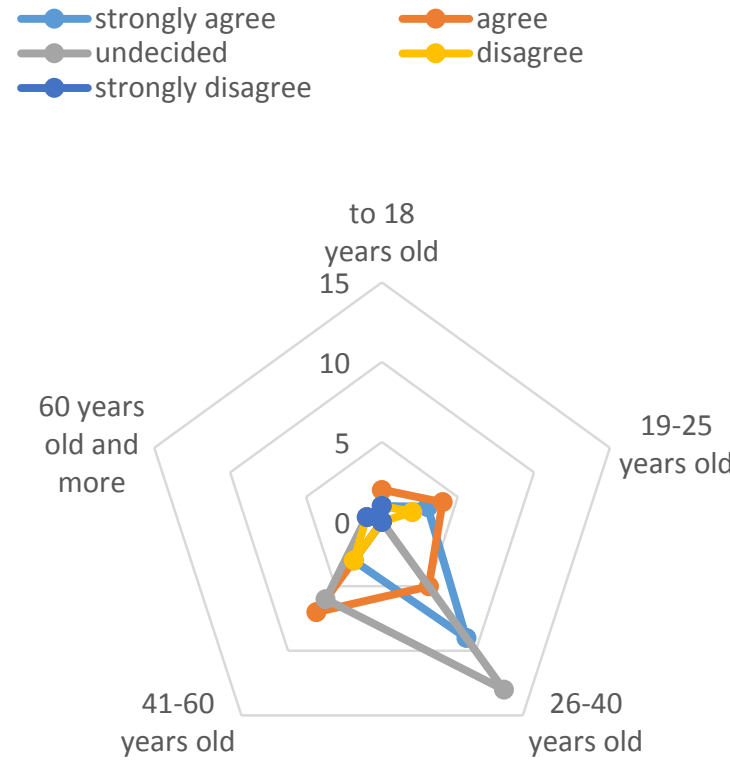

Figure 4a. Women's opinion on the need to develop the car sharing service in Poland. Source: the authors' own studies.

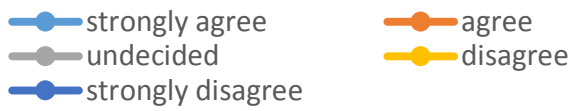

to 18

years

old

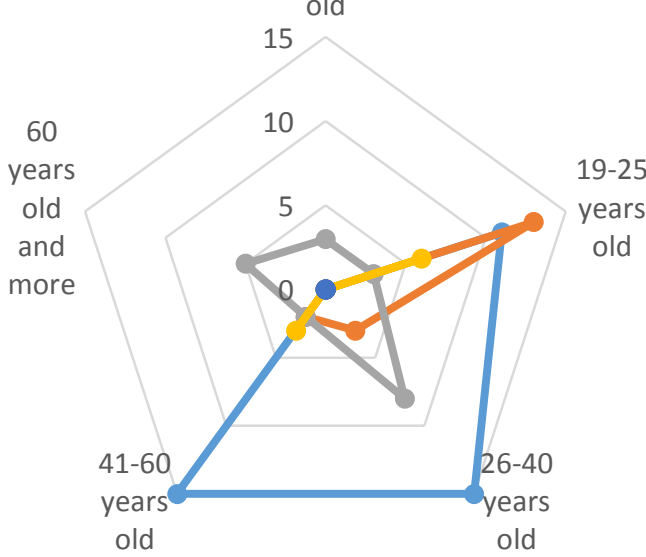

Figure 4b. Men's opinion on the need to develop the car sharing service in Poland. Source: the authors' own studies. 
In the research conducted in this article, the respondents also expressed their opinion on the need to develop the car sharing service in Poland. In this case, women are more sceptical; those aged 26-40 most often stated that they definitely think that there is such a need, while women aged 41-60 say that such a service is rather needed. On the other hand, men in the age range of 26-40 and 41-60 years old stated that the development of this area is definitely needed. Men aged 19-25 assessed the need for moderation as rather needed. The results are presented in Figure $4 \mathrm{a}$ and $4 \mathrm{~b}$.

\section{Analysis of the diversity of perception of the original features of the car sharing service perceived by users belonging to two categories of sex variable - grouping variable $X_{p}$}

In order to define more precisely how the different groups perceive car sharing services, a discriminatory analysis of the perception of the service by users belonging to the two categories of variable $X_{p}-$ sex - has been carried out. For the variable grouping $X_{p}-$ sex (there are two categories: women, $m e n)$, as a result of the progressive stepwise analysis, the general model defined by three variables was separated - Table 2 .

Table 2.

General model of discriminatory function; $X_{p}$-sex variable; independent variables characteristics of the carrier share service perceived by users

\begin{tabular}{|c|c|c|c|c|c|c|c|}
\hline \multirow{2}{*}{ Effect } & \multicolumn{6}{|c|}{ Summary of stepwise regression; variable: sex Forward only P to enter: .05, P to remove: .05 } \\
\cline { 2 - 7 } & Steps & $\begin{array}{c}\text { Degr. of } \\
\text { Freedom }\end{array}$ & $\begin{array}{c}\text { F to } \\
\text { remove }\end{array}$ & $\begin{array}{c}\text { P to } \\
\text { remove }\end{array}$ & $\begin{array}{c}\text { F to } \\
\text { enter }\end{array}$ & $\begin{array}{c}\text { P to } \\
\text { enter }\end{array}$ & $\begin{array}{c}\text { Effect } \\
\text { status }\end{array}$ \\
\hline 2 & Step Number 4 & 1 & 13.53304 & 0.000331 & & & In \\
\hline 9 & & 1 & 11.63217 & 0.000843 & & & In \\
\hline 12 & & 1 & 9.44075 & 0.002542 & & & In \\
\hline
\end{tabular}

Source: the authors' own studies.

From the data shown in Table 2 it appears that in the perception variation being examined there are three primary characteristics, i.e.:

$\mathrm{Y}_{2}$ - "Car rental prices are competitive",

$\mathrm{Y}_{9}$ - "The city parking service is free of charge for those using a rented car",

$\mathrm{Y}_{12}$ - "Companies providing car sharing services have modern cars".

In the case under consideration, the "gender" variable grouping has two categories, so the subject of canonical analysis is one discriminatory function. By verifying the significance of separate discriminant functions defined by the three above-mentioned original features, the results presented in Table 3 were obtained. 


\section{Table 3.}

Results of verification of the statistical significance of the discriminatory function; chi-sqr. test; grouping variable $X_{p}$ - sex; independent variables - primary features of the functional component of the car sharing service perceived by users

\begin{tabular}{|l|c|c|c|r|r|r|}
\hline \multirow{2}{*}{ Removed } & \multicolumn{2}{|c|}{ Chi-Square Tests with Successive Roots Removed Sigma-restricted parameterization } \\
\cline { 2 - 7 } & $\begin{array}{c}\text { Eigen- } \\
\text { value }\end{array}$ & Canonical R & $\begin{array}{c}\text { Wilk's } \\
\text { Lambda }\end{array}$ & \multicolumn{1}{c|}{ Chi-Sqr. } & \multicolumn{1}{c|}{ df } & \multicolumn{1}{c|}{ p-value } \\
\hline 0 & 0.717810 & 0.646424 & 0.582137 & 68.44285 & 37.00000 & 0.001263 \\
\hline
\end{tabular}

Source: the authors' own studies.

The data presented in Table 3 show that the separated function is statistically significant at the level of $p<<\alpha=0.05$. The standardized coefficients of this function are presented in Table 4.

\section{Table 4.}

Standardized discriminant function coefficients; grouping variable $X_{p}-$ sex; independent variables - the original features of the functional component of the car sharing service perceived by users

\begin{tabular}{|c|c|}
\hline \multirow{2}{*}{ Effect } & $\begin{array}{l}\text { Standardized Canonical Discriminant Function Coefficients Sigma-restricted } \\
\text { parameterization }\end{array}$ \\
\cline { 2 - 3 } Intercept & Function 1 \\
\hline 2 & 0.00000 \\
\hline 9 & -0.20530 \\
\hline 12 & 0.63685 \\
\hline Eigenvalue & -1.35693 \\
\hline $\begin{array}{c}\text { Cum. } \\
\text { Prop. }\end{array}$ & 0.71781 \\
\hline
\end{tabular}

Source: the authors' own studies.

The special canonical form of discriminative function 1 in the case of the variable grouping $\mathrm{X}_{\mathrm{p}}-$ sex can be thus presented as follows:

$$
\mathrm{Z}=-0.21 \mathrm{Y}_{2}+0.64 \mathrm{Y}_{9}-1.36 \mathrm{Y}_{12} \text {. }
$$

From the data presented in Table 4 it follows that the discriminant function 1 is determined by the negative coefficients of variables $\mathrm{Y}_{2}$ and $\mathrm{Y}_{12}$, and by the positive coefficient of variable $\mathrm{Y}_{9}$.

The data in Table 4 also show that in the case of a discriminatory function 1, the primary feature is the most diversified of the considered perception: $\mathrm{Y}_{12}$ - "car sharing services have modern cars".

Table 5 presents the mean values of canonical variables for individual categories of the variable grouping $X_{p}$ - sex. 


\section{Table 5.}

Average values of canonical variables; grouping variable $X_{p}-$ sex; independent variables primary features of the functional component of the car sharing service perceived by users

\begin{tabular}{|l|c|c|}
\hline \multirow{2}{*}{ Root } & \multicolumn{2}{|c|}{ Class Means for Canonical Variables Sigma-restricted parameterization } \\
\cline { 2 - 3 } & women & men \\
\hline 1 & 0.999112 & -0.708673 \\
\hline
\end{tabular}

Source: the authors' own studies.

From the data shown in Tables 4 and 5 it appears that if the primary characteristic is highly assessed:

$\mathrm{Y}_{9}$ - "The city parking service is free of charge for those using a rented car" and low scores will be assigned to the original characteristics:

$\mathrm{Y}_{2}$ - "Car rental prices are competitive",

$\mathrm{Y}_{12}$ - "Companies providing car sharing services have modern cars", the likelihood that the evaluators were women is greater. Opposed evaluation of these two subsets indicates a high probability that the evaluators were men.

As it seems, women have pointed to the availability of car parking spaces for shared cars as part of the car sharing service; parking costs, especially in city centres, are currently very high.

High assessments for factors $\mathrm{Y}_{2}, \mathrm{Y}_{12}$ indicate a high probability that men were evaluators, which means that the main distinguishing factors are the competitive rental prices of cars but also the modern fleet available from the offer of car sharing companies, since these are most often new cars.

Although the analysed case focused on the verification of the service based on the gender of the respondents, the assessment of the car sharing service by its users depends on many different factors, not only gender, but also age, place of residence or professional status.

\section{Conclusion}

The major conclusion of the study was that the car sharing service is quite a modern service available in Poland. It is often perceived by users as an innovation that should be tried. Car sharing provides a flexible alternative that meets various transport needs around the world, while reducing the negative impact of ownership of private vehicles. As already mentioned, the market of transport services is constantly growing. The increasing number of cars causes their users more and more problems, fewer and fewer parking spaces, introducing in many cities legal regulations limiting driving own cars through city centres. For these reasons, the interest in the new service is constantly growing. Although the car sharing service is an interesting alternative to owning a car, the car owners are unlikely to get rid of their cars in order to use 
the car-hire service. There are several advantages of such a solution, for example, suggestions for using special lanes on the road, the so-called bus lanes, special parking spaces, the possibility of driving into areas closed for private cars. Certainly, these benefits will encourage more users to use car sharing services more often and more widely. However, it depends on the mentality of drivers and is a matter of getting used to having a car. It is difficult to change. However, this service is becoming more and more popular and its background lies in the phenomenon of sharing economy which still has a growing number of supporters.

In conclusion, it should be noted that car sharing companies will certainly grow, offering additional benefits to users. This does not mean, however, that traditional cars will disappear from Polish roads. The conducted research does not indicate clearly what will be the unambiguous fate of this service on the Polish market. The research calls for future exploration of the issues of sharing economy such as for example Uber or BlaBlaCar. A comparison of researches may contribute to an attempt to define a new trend and to identify the needs of new customers in the context of ownership. It takes time to change the business models of companies offering sharing services, to make them cheaper and more accessible, and for drivers to be more aware of the solution for efficient travelling.

\section{References}

1. Bellos, I., Ferguson, M., \& Toktay, L.B. (2017). The car sharing economy: Interaction of business model choice and product line design. Manufacturing \& Service Operations Management, 19(2), 185-201.

2. Guo, Y., Xin, F., Jia, Q., Barnes, S., \& Wang, Y. (2018). How traditional incumbents react to sharing economy entrants? Evidence from the car industry.

3. Leveque, F. (2011). A strategic insight into carsharing market developments and dynamics.

4. Łuczak, M., Małys, Ł., Jedlińska, M., Senkus, P., Skrzypek, A., Przybylski, R., Zdziarski, M. (2016). Współczesne koncepcje i trendy w branży motoryzacyjnej. Advertiva.

5. Münzel, K., Boon, W., Frenken, K., \& Vaskelainen, T. (2018). Carsharing business models in Germany: Characteristics, success and future prospects. Information Systems and e-Business Management, 16(2), 271-291.

6. PwC (2016). Współdziel i rządź! Twój nowy model biznesowy jeszcze nie istnieje.

7. Shaheen, S. A. (2016). Mobility and the sharing economy. Transport Policy, 51 (Supplement C), 141-142.

8. Sztokfisz, B. (2018). Rynki peer-to-peer jako współczesny przejaw wolności gospodarczej. Studia Ekonomiczne, 349, 232-242. 